\title{
Unity or Variety: the Curriculum Construction of Undergraduate Business English Major in Shandong Province
}

\author{
Shuai Wang, 2 \\ ${ }^{1}$ Government Policy and Public Administration Dept., Graduate School of the Chinese Academy of Social Sciences \\ Beijing City, China \\ ${ }^{2}$ Business English Dept., School of Translation and Interpreting \\ Qufu Normal University \\ Rizhao City, Shandong Province, China \\ 944783205@qq.com
}

\begin{abstract}
This essay is designed to explore similarities and differences of Curriculums of undergraduate Business English major of five universities/colleges in Shandong Province. A descriptive study is used to illustrate the current situation of undergraduate Business English education based on field trips, internet research and interviews with deans of Business English Departments from the five schools. A comparative study is used to contrast the five curriculums and National Standard. They do not show distinctive and specific directions of talents cultivation. There is big gap between the 5 curriculums and the National Standard. This study is the first attempt focusing on the curriculums of undergraduate Business English major in Shandong. It will be significant to give curriculum designers a guide to improve in order to cultivate students which are needed by the market and serve local economic development better.
\end{abstract}

Keywords—Business English; curriculum; Shandong province

\section{INTRODUCTION}

Accompany with the globalization and opening-up of China, especially after the launch of "Going Global" strategy and "Belt and Road Initiative", talents who can use English to communicate fluently and effectively in a business context are in great need. According to the statistics issued by the National Bureau of Statistics of the People's Republic of China (NBS) in 2014, foreign direct investment reached a new high of USD 87.8 billion; China became the third largest foreign investment country. However, qualified international operation and management talents were no more than $8,000^{1}$ which is far behind the need. The relevant talents education, especially undergraduate education, couldn't keep pace with the fast economic development. Actually, the history of Business English education in China could date back to the 1730s[1]. However, until 2007, University of International Business and Economics (UIBE) became the first one to eat crab and carried out a pilot project which was approved by the Ministry of Education of People's Republic of China (MEPRC) to start

\footnotetext{
1 Professor Lifei WANG of School of English Studies of University of International of Business and Economics mentioned several times during some Business English Meetings.
}

This research is supported by Foreign Language Program of Shandong Social Science Planning Fund Program-Strategic Research on the Curriculum Design of Undergraduate Business English Major in Shandong Province (11CWZJ48). undergraduate Business English education, designing a fouryear curriculum[2]. In 2012, Business English as an undergraduate major, equals to English major, was officially written into the Category of Undergraduate Majors issued by the MEPRC. From 2007 to 2015, 293 universities/colleges have successfully applied for the major.

According to Hutchinson and Waters[3], the approach to ESP should be based on the learner's needs in their respective specialized subjects. Now, "it has shifted towards developing communication skills and learning is very much directed by specific learner's needs for mastering the language.” Thus, Business English as a branch of ESP (English for Specific purposes) is strongly mingled with market needs. According to the NBS, GDP of Shandong ranks the third among thirty provinces in China in 2015. Meanwhile, 10 universities/colleges--Shandong Business and Technology University (SBTU), Qufu Normal University (QNU), Shandong University of Finance and Economics (SUFE), Shandong Agricultural University (SAU), Dongchang College of Liaocheng University (DCLU),Shandong Political Science and Law (SPSL), Linyi University (LU), Binzhou College (BC), Shandong Women's University (SWU) and Qindao College of Qingdao Science and technology University (QCQSTU)--have undergraduate Business English major which accounts for only $3.4 \%$ in China and makes the relevant talents education lag far behind the economic growth. In this essay, the author chose the first 5 schools which applied for the major earlier and have graduates already as research objectives and try to answer the following questions: What are the curriculums in the five universities/colleges, similar or different? How can the curriculums comply with the National Standard of Business English Undergraduate Major Teaching Quality (National Standard) as well as serve the development of local economy?

\section{LITERATURE REVIEW}

What is business English? According to Ellis and Johnson[4], "Business English implies the definition of a specific language corpus and emphasis on particular kinds of communication in a specific context." In this definition, three phrases need to be highlighted: specific language corpus, 
communication and specific context. A business English vocabulary may exclusively exist in business English text, such as hedging, transaction. Communication is a two-way process, during the process, the listener is also a speaker, he/she listens, understands and then gives responses in a verbal or non-verbal way. In the process, language skills are needed: listening, speaking, reading, writing as well as cross-cultural awareness. Some words and expressions may be used both in General English and Business English. Thus, they have completely different meanings, such as 'performance', in business context, mainly means any recognized accomplishment at work, while in entertainment, it means the act of presenting a play or a piece of music or other entertainment. "Minutes" in General English means the unit of time, while in business English, minutes mainly refers to the record of a meeting. Zhang[5] proposed a more complete definition: "Business English involves the teaching of the system of strategic communication in the social and economic domain of international business in which participants, adopting/ adapting business conventions and procedures, make selective use of lexico-grammatical resources of English as well as visual and audio semiotic resources to achieve their communicative goals via the writing modality, speaking modality, and/or multi-modality." The two definitions both emphasize "communication", whereas Zhang[6] gave specific objectives about learning Business English, that is cross-cultural business communication skills which are strengthened on the basis of understanding specific meanings of words and expressions under any non-private context.

Curriculum as a core for cultivating talents plays a critical role in achieving teaching objectives. In western countries, researches on Business English curriculums are based on ESP's need analysis[7-11,4]. "ESP courses set out to teach language and communication skills that specific groups of language learners need or will need to function effectively in their disciplines of study, professions or workplaces.”[12] In China, researches on the topic can be divided into three stages. Before 1990s, Business English is called English for Foreign Trade. According to Chen and Wang[13], curriculums including courses called Correspondence for Foreign Trade, Oral English for Foreign Trade and Selected Reading on International Business and Economics from Western Newspapers and Journals are designed mainly to serve foreign trade. The 1990s saw a boom in Business English teaching and learning in China[5]. More than 300 universities/colleges had Business English as a direction below English major. However, business courses are relatively independent from language skills courses; they are like two parallel lines. After 2006, Business English was approved to be an independent undergraduate major, courses system construction, balance and interrelations between English language skills courses and business knowledge courses started to be studied by researchers and curriculum designers. In 2014, the National Standard ${ }^{2}$ was

\footnotetext{
2 Since then, the National Standard has been revised many times by the Foreign Language Teaching Advisory Board under the Ministry of Education of China. Every school has already started to revise or redesign their own curriculums based on the Standard. However, until the paper is finished, the Standard has not been published officially.
}

proposed by Foreign Language Teaching Advisory Board under the Ministry of Education in which the curriculum is updated to five modules with recommended proportions: English language skills (40\%-60\%), business knowledge (25\%$35 \%$ ), humanities (5\%-10\%), cross-cultural communication skills (5\%-10\%) and practical courses[14]. The National Standard provides a frame work for the curriculum design.

\section{Methodology}

This thesis applied the National Standard as a framework into classifying and comparing the curriculums of the five schools mentioned above. Field trips, internet research and interview are used in order to gather information on the overall situation of Business English education. The 5 interviewees are all deans of Business English Department in their schools respectively who are very familiar with the major, the National Standard and current situation of the major construction. They are also involved in or responsible for designing and improving the curriculum as well. Open questions are mainly asked during the interview.

\section{RESUltS AND DisCUSSIONS}

According to the information collected, the essay attempts to find answers to the questions mention above. I tend to agree with the idea that biggest obstacle of Business English education development is due to the lack of faculty who major in Business English, International Business or other related subjects (as shown in TABLE I). There are very few professors, associate professors and PHDs in Business English Department or Business English Teaching Group in the five schools. The quality of teachers will definitely affect the quality of students' cultivation. What's more, opinions from professors and academic leaders seem to be hardening against the application. They hold the assumption that Business English would ruin the humanity and culture of original English major due to its interdisciplinary. On the other hand, the increasing unemployment of English graduates can prove that the cultivation objectives of English major could not meet the actual needs of the market. Dynamic adjustment mechanism of course setting should be implemented as soon as possible in order to serve the development of local companies and economy.

TABLE I. FACULTY RESOURCES

\begin{tabular}{|c|c|c|c|c|c|}
\hline Numbers of Faculty & SBTU & QNU & SUFE & SAU & DCLU \\
\hline All faculty & 12 & 9 & 12 & 11 & 6 \\
\hline Professor & 1 & 1 & 0 & 2 & 0 \\
\hline Associate professor & 5 & 2 & 9 & 1 & 1 \\
\hline PHD and PHD student & 0 & 3 & 4 & 3 & 0 \\
\hline Double Qualified Teacher & 3 & 3 & 2 & 0 & 0 \\
\hline
\end{tabular}


Five curriculums ${ }^{3}$ are thoroughly studied; all the courses except common required courses are classified into four modules according to the National Standard: English language skills, business knowledge, humanity and cross-cultural modules. The first module accounts for an appropriate percentage complying with the National Standard, while the latter three do not meet the standard which needs to be improved. This phenomenon shows that all schools did not study the National Standard carefully, did not pay attention to the humanity and cross-cultural quality of students as well. (As shown in TABLE II)

Most of the courses of the four modules are similar. In the English language skills module, there are Comprehensive Business English, Business Oral English, Business Listening, Business Writing, Business Translation, Business Interpreting, English Pronunciation, English Grammar in all five schools which are fundamental to cultivate students' communication skills. In humanity module, three of them offer American Literature, British Literature and Introduction of Englishspoken Countries. DCLU only has one course called Introduction of Britain and America. In cross-cultural module, SBTU does not have a course related, while the other three schools have only one course called Introduction to Crosscultural Communication. In business knowledge module, varieties appear. All the five schools have Economics, International Trade: Theories and Practice, International Management, International Business Law. While there is accounting in Discipline basic courses of DCLU's curriculum. There are three sub-directions below Business English major in DCLU: International Business, International trade, International Conference and Exhibition, among which International Business and International Trade are also seen in the curriculum of SBTU. While SAU has Agricultural English, QNU has Chinese Tradition and Translation as their characteristic courses.

TABLE II. CREDITS PROPORTION

\begin{tabular}{|c|c|c|c|c|}
\hline & $\begin{array}{c}\text { English } \\
\text { Language }\end{array}$ & $\begin{array}{c}\text { Business } \\
\text { Knowledge }\end{array}$ & Humanity & $\begin{array}{c}\text { Cross-cultural } \\
\text { communication }\end{array}$ \\
\hline SBTU & $39.3 \%$ & $16.7 \%$ & $1.3 \%$ & $0.5 \%$ \\
\hline QNU & $42.5 \%$ & $6.25 \%$ & $1.88 \%$ & $1.25 \%$ \\
\hline SUFE & $40 \%$ & $5.3 \%$ & $2.7 \%$ & $1.3 \%$ \\
\hline SAU & $47.3 \%$ & $16 \%$ & $5.3 \%$ & $2 \%$ \\
\hline DCLU & $40.5 \%$ & $9.3 \%$ & $0.6 \%$ & $0.6 \%$ \\
\hline $\begin{array}{c}\text { National } \\
\text { Standard }\end{array}$ & $40 \%-60 \%$ & $25 \%-35 \%$ & $5 \%-10 \%$ & $5 \%-10 \%$ \\
\hline
\end{tabular}

\footnotetext{
${ }^{3}$ These five curriculums collected are all the first versions which are designed when the five school got approval from the Ministry of Education to start undergraduate business English education in their schools respectively in 2015. Now the curriculums have been revising accompany with the launching of the National Standard.
}

From the comparison above, we can see that most of the credits in the five curriculums are strongly focused in English language skills module. In business knowledge module, none of them meet the requirement of the National Standard. In humanity module, only in SAU, it accounts for more than $5 \%$. In cross-cultural module, none of them meet the requirement of the National Standard, which showed clearly that all the curriculums need to be revised and improved. Because of the lack of teachers who can use English to teach economics, international business law, international management and marketing, accounting, etc., the curriculums do not show distinctive cultivation directions in course setting.

\section{SUMMARIES}

It is taken for granted that every curriculum must have its own characteristic which combines their school's characteristics and the need of local economy. I hesitate to agree with the opinion. In the undergraduate level of Harvard, general education of humanities is emphasized. If the courses are limited in a very narrow direction, it won't be helpful for students looking for jobs. It is believed that a specific direction may prevent graduates of the five schools from direct competition in job interviews. From my point of view, it is undoubtedly true that the graduates will face the competition from International Trade and International Business majors. The objectives of Business English undergraduate major should focus on the cross-cultural business communication in the International Supply Chain. Business English majors should be bridges not only between two languages but also two cultures should smooth the communication barriers in order to improve work efficiency.

All the five schools started to recruit students in recent three years with the enrollment of no more than 120 students per year, and all of the curriculums are desperately needed to be improved according to the National Standard. Business English undergraduate major is like an infant, It deserves great attention as a new and interdisciplinary field. BE teachers and students should have confidence, determination as well as standardization. A need analysis needs to be completed before curriculum editing in order to make sure that the curriculums follow a market-oriented principle as well as the National Standard.

\section{REFERENCES}

[1] Mo, Z. S. \& Xiao, Y. N. (2012). The Origin and Linguistic Property of Early Business English in China. Journal of Hunan University (Social Science), 26.2, 86-89.

[2] Chen J. P. (2010). Discussions on Few Questions on the Newlyestablished Business English BA Program. China University Teaching, 6, 45-48

[3] Hutchinson. \& Waters. (1987). English for Specific Purposes. New York: Cambridge University Press.

[4] Ellis, M., \& Johnson, C. (2002). Teaching Business English. Shanghai: Shanghai Foreign Languages Education Press.

[5] Zhang Z.C. (2007). Towards an Integrated Approach to Teaching Business English: A Chinese Experience. English for Specific Purposes, 26,399-410

[6] Zhang Z. C. (2005). Business English: A Discourse Approach. Beijing: International Business and Economics Press. 
[7] Chambers, F. (1980). A re-evaluation of needs analysis in ESP. The ESP Journal, 1.1, 25-33.

[8] West, R. (1997). 'Needs Analysis: State of the Art' in R. Howard and G.Brown (eds) Teacher Education for LSP. Clevedon: Multilingual Matters.

[9] Dudley-Evans, T., \& St John, M.J. (1998). Developments in English for specific purposes: A multi-disciplinary approach. Cambridge: Cambridge University Press.

[10] Gusti, A. (1999). The Role of Need Analysis in English for Specific Purposes. TEFLIN Journal, 1.
[11] Sysoyev, P. V. (2001). Developing an ESP Course: A Framework for a Learner-Centred Classroom. The ESP Newsletter, Issue 1.

[12] Basturkmen, H. (2014). Developing Courses in English for Specific Purposes. Shanghai: Shanghai Foreign Languages Education Press.

[13] Chen, Z. M. \& Wang, L. F. (2009). Developing National Curriculum for BA Program in Business English of China. China Foreign Languages, 6.4, 4-12

[14] Wang, L. F. \& Ye, X. G. \& Yan, M. \& Peng, Q. L. \& Xu, D. J. (2015). Explanations on the National Standard of Teaching Quality of Business English BA Program. Foreign Language Teaching and Research, 47. 2, 297-302 